\title{
The Performance of Zea mays as Influenced by NPK Fertilizer Application
}

\author{
Kolawole Edomwonyi LAW-OGBOMO, Joyce Egberanwen LAW-OGBOMO \\ Benson Idahosa University, Department of Agriculture, PMB 1100,Benin City, Nigeria; kolalawogbomo@yahoo.com (correspondingauthor)
}

\begin{abstract}
Field trials were made to estimate the effect of NPK 15:15:15 fertilizer on the growth and yield of maize were conducted over a two year period. NPK fertilizer applications significantly increase plant height, stem girth, number of leaves, leaf area, leaf area index, dry matter accumulation and yield. The optimum level of NPK 15:15:15 fertilizer for successful production of maize grains was $400(60 \mathrm{~kg} \mathrm{~N}$ $+27.16 \mathrm{~kg} \mathrm{P}+49.80 \mathrm{~kg} \mathrm{~K}) \mathrm{kg} / \mathrm{ha}$ compound fertilizer based on the fact that it had the greatest dry cob yield (12.44 t / ha), grain yield $(7.95 \mathrm{t} / \mathrm{ha})$, relative grain yield $(2.26)$ and 100 -seeds weight $(11.62 \mathrm{~g})$.
\end{abstract}

Keywords: Growth, NPK fertilizer, plant height, stem girth and yield

\section{Introduction}

Wheat, rice and maize are the most important cereal crops in the world but maize is the most popular due to its high yielding, easy of processing, readily digested and costs less than other cereals (Jaliya et al., 2008). Maize as a major source of carbohydrate is used as food, in livestock diet, in the textile industry and also in the pharmaceutical industry.

Maize has immense potential in the tropics and yield of up to $7.5 \mathrm{t} /$ ha can be obtained if the crop is properly managed. Unfortunately, yields are still generally below $5 \mathrm{t} / \mathrm{ha}$ (FAO. 2007) and this had cause inadequacy of maize for its numerous usages. Yield differences between temperate and tropical areas have been attributed to low nutrient status of tropical soils especially nitrogen, phosphorus and potassium resulting from the practice of slash and burn farming system associated with bush fallow and with excessive leaching of the soil nutrients. This system is presently unsustainable due to high population pressure and other human activities which have resulted in reduced fallow period (Steiner, 1991).

The low fertility status of most tropical soils hindered maize production as maize has a strong exhausting effect on the soil. It was generally observed that maize fail to produce good grain in plots without adequate nutrients (Adediran and Banjoko, 2003). Inorganic fertilizer exert strong influence on plant growth, development and yield (Stefano et al., 2004).The availability of sufficient growth nutrients from inorganic fertilizers lead to improved cell activities, enhanced cellk multiplication and enlargement and luxuriant growth (Fashina et al., 2002). Luxuriant growth resulting from fertilizer application leads to larger dry matter production (Obi et al., 2005) owing better utilization of solar radiation and more nutrient (Saeed et al., 2001).
The use of inorganic fertilizers on crops increased yield as Adediran and Banjoko (2003) observed that there was substantial depletion of nutrients with the yields where no NPK fertilizer was applied. This position was reported by Uyovbisere et al (2001) who reported that there was substantial depletion of nutrients when no NPK fertilizer was applied and nitrates and available phosphorus were substantially reduced with cropping in humid zone of Southwestern Nigeria. Conflicting results about the benefits and adverse effects of fertilizer have however been found in literatures. Ayoola and Adeniyan (2006) had reported that the use of inorganic fertilizer has not been helpful under intensive agriculture because it is often associated with reduced yield, nutrient imbalance, leaching and pollution of groundwater (Sridhar and Adeoye, 2003). This is not unexpected due to lack of uniformity over a wide range of ecological conditions, especially soil type, under which maize is grown. This could also be likely due to differences in the pre-cropping nutrient status and partly due to difficulty in interpreting the results of soil analysis. Plant analysis is a useful supplement to soil analysis where the soil analysis presents difficulties in assessing available nutrients.

In view of inconsistency in the fertilizer and increasing cost of production associated with its usage, field trials were conducted in 2005 and 2006 to determine the appropriate NPK 15:15:15 rate that will produce the optimum yield.

\section{Materials and Methods}

Field trials were carried at Teaching and Research Farms, Benson Idahosa University, Benin City $\left(5^{\circ} 04^{\prime} \mathrm{N}\right.$ and $5^{\circ} 45^{\prime} \mathrm{E}$ ) between March and June in 2005 and 2006. The site is a typical humid forest environment with loam sand characterized with low nutrient reserve and derives 
60

from coastal plain sand classified as ultisols. The site had been cultivated in previous years; there was no record of fertilizer application.

Soil was well drained, of gentle slope. The composite soil sample $(0-30 \mathrm{~cm}$ depth) taken from the site and analysed for routine soil physical and chemical properties using standard laboratory procedures outlined by Mylavapus and Kennelley (2002). The routine analysis showed that it had $\mathrm{pH}\left(\mathrm{H}_{2} \mathrm{O}\right) 5.99$, total nitrogen $(\%) 0.16$, organic carbon (\%) 1.80, available phosphorus (mg / kg) 4.19, exchangeable $\mathrm{K}(\mathrm{cmol} / \mathrm{kg}) 0.06$, exchangeable $\mathrm{Ca}(\mathrm{cmol} /$ $\mathrm{kg}) 0.75$, exchangeable $\mathrm{Mg}(\mathrm{cmol} / \mathrm{kg}) 0.12$, exchangeable $\mathrm{Na}(\mathrm{cmol} / \mathrm{kg}) 0.10$, clay (\%) 4.00, silt (\%) 14.00 and sand (\%) 82.00 .

The trials were laid down in a randomized complete block design. The treatments included four NPK fertilizer rates viz. $0(0 \mathrm{~kg}+0 \mathrm{~kg} \mathrm{P}+0 \mathrm{~kg} \mathrm{~K}), 200(30 \mathrm{~kg}+13.58$ $\mathrm{kg} P+24.90 \mathrm{~kg} \mathrm{~K}), 400(60 \mathrm{~kg}+27.16 \mathrm{~kg} \mathrm{P}+49.80 \mathrm{~kg}$ $\mathrm{K})$ and $600(90 \mathrm{~kg}+40.70 \mathrm{~kg} \mathrm{P}+74.70 \mathrm{~kg} \mathrm{~K}) \mathrm{kg} / \mathrm{ha}$ of compound fertilizer.

Three seeds of maize variety DMSRW (Downy Mildew Streak Resistant White) sourced from IITA (International Institute for Tropical Agriculture), Ibadan were sowed on the field at a spacing of $75 \times 25 \mathrm{~cm}$ in March in both years. The resulting seedlings were thin to one per stand, two weeks after planting (WAT). Weeding commenced at 2 WAT and subsequently weeding was carried out as at when due. Recommended practices for disease and insect pest control were followed.

The application of fertilizer of NPK 15:15:15 fertilizer was carried out at two equal splits at 2 and 4 WAT using ring method. Eight plants were randomly selected per plot for determination of growth and yield parameters. The growth parameters assessed included plant height $(\mathrm{cm})$, stem girth $(\mathrm{cm})$, number of leaves, leaf area per plant and leaf area index (LAI) and total dry matter $\left(\mathrm{t} \mathrm{ha}^{-1}\right)$. At harvest, the cobs were harvested fresh and weighed. The cobs were dried and re-weighed. The grain on the cobs were shelled and equally weighed. Total dry matter (TDM) was determined by oven dried in brown envelope at $75^{\circ} \mathrm{C}$ until constant weight was attained (ISTA, 1993).

Analysis of variance was carried out on each of the observations recorded for each year of study, followed by combined analysis over two years using SAS-GLM procedure (SAS Institute, 2004). The Least Significant Difference (LSD $\mathrm{P}<0.05)$ test was used for detecting differences between means.

\section{Results and discussion}

The effect of NPK fertilizer application on plant height and stem girth is showed in Tab. 1. NPK fertilizer application significantly affected plant height and stem girth (Tab. 1). Plant height was increased with successive increment in fertilizer application rate up to $600 \mathrm{~kg} /$ ha. Maize plants were tallest in those plants that received 600
Tab. 1. Effects of NPK 15:15:15 fertilizer on the height and stem girth of maize (Zea mays)

\begin{tabular}{ccccccc}
\hline $\begin{array}{c}\text { Fertilizer } \\
\text { rate }\end{array}$ & \multicolumn{3}{c}{ Plant height $(\mathrm{cm})$} & \multicolumn{3}{c}{ Stem girth $(\mathrm{cm})$} \\
\hline$\left(\mathrm{kg} \mathrm{ha}^{-1}\right)$ & 4 WAP & 6 WAP & 8 WAP & 4 WAP & 6 WAP & 8 WAP \\
\hline 0 & 35.19 & 119.18 & 148.20 & 6.10 & 6.25 & 6.34 \\
200 & 38.44 & 128.40 & 158.30 & 6.30 & 6.38 & 6.45 \\
400 & 45.24 & 135.55 & 161.15 & 6.96 & 6.60 & 7.90 \\
600 & 49.35 & 138.25 & 168.35 & 6.75 & 7.40 & 7.67 \\
Mean & 42.06 & 130.35 & 158.98 & 6.53 & 6.66 & 7.10 \\
LSD & & & & & & \\
$(\mathrm{P}<0.05)$ & 2.63 & 6.13 & 9.25 & 0.48 & 0.68 & 0.79 \\
\hline
\end{tabular}

$\mathrm{kg}$ NPK ha ${ }^{-1}$ than those that received lower rate of application during all the sampling periods (Tab. 1). This observation is in agreement with the findings of Babatola et al (2002) who reported that increasing level of fertilizer application was observed to increased growth and yield of crops. The significant increase in plant height reflects the effect of fertilizer nutrients, N, P and K. The untreated plants were almost stunted in growth as they had to rely on the native soil fertility which, from the result of chemical analysis was deficient in these nutrients. The height of plant is an important growth character directly linked with the productive potential of plants in terms of grains. An optimum plant height is claimed to be positively correlated with productivity of plant (Saeed et al., 2001).

NPK fertilizer application increased the stem girth (Tab. 1). The maize plants that received $600 \mathrm{~kg} /$ ha had the greatest stem girth irrespective of the sampling period. Uptake and utilization of applied fertilizer in both years witness better responses in terms of stem girth compared with the non-fertilized plants. Increase in stem girth is a reflection of retention of appreciable amount of assimilates in the stem for leaf production.

The number of leaves per plant during the three sampling periods was dependent on fertilizer rate as it increased with increase in fertilizer rate at 4, 6 and 8 WAP (Tab. 2). Plants fertilized with $600 \mathrm{~kg} \mathrm{NPK \backslash ha} \mathrm{had} \mathrm{the}$ highest number of leaves in all sampling periods in both years which were $100 \%, 62 \%$ and $277 \%$ increase over the unfertilized plants at 4, 6 and 8 WAP, respectively. The number of leaves was significantly correlated with fertilizer rate at 6 WAP $(r=0.72)$ and at 8 WAP $(r=0.60)$. These findings are in lined with the view of Stefano et al (2001) who reported that fertilizer application resulted in luxuriant growth with excessive leaves. Higher number of leaves on fertilizer treated plants contributes to a better canopy and suppression of weeds.

There was significant difference among treatment means in response to leaf area per plant (LA) at the three sampling periods (4, 6 and 8 WAP) (Tab. 2) in both cropping seasons. Plants fertilized with $600 \mathrm{~kg} \mathrm{NPK} \mathrm{ha}^{-1}$ had the greatest LA at 4, 6 and 8 WAP (Tab. 2). At all sampling periods, the LA was significantly correlated with the 
Tab. 2. Effects of NPK 15:15:15 fertilizer application on the growth of maize (Zea mays)

\begin{tabular}{cccccccccc}
\hline Fertilizer rate & \multicolumn{3}{c}{ Number of leaves } & \multicolumn{3}{c}{ Leaf area/ plant $\left(\mathrm{cm}^{3}\right)$} & \multicolumn{3}{c}{ Leaf area index } \\
\hline$\left(\mathrm{kg} \mathrm{ha}^{-1}\right)$ & \multicolumn{3}{c}{ Weeks after planting } & \multicolumn{3}{c}{ Weeks after planting } & \multicolumn{3}{c}{ Weeks after planting } \\
& 4 & 6 & 8 & 4 & 6 & 8 & 4 & 6 & 8 \\
0 & 2.50 & 5.25 & 8.50 & 5.20 & 12.97 & 46.75 & 0.003 & 0.007 & 0.025 \\
200 & 2.50 & 7.50 & 14.20 & 11.40 & 57.90 & 352.16 & 0.006 & 0.031 & 0.188 \\
400 & 5.00 & 8.25 & 25.00 & 50.35 & 161.87 & 1225.00 & 0.027 & 0.086 & 0.653 \\
600 & 5.00 & 8.50 & 32.10 & 62.15 & 171.28 & 1600.00 & 0.033 & 0.091 & 0.853 \\
Mean & 3.75 & 7.38 & 19.95 & 32.28 & 101.01 & 805.98 & 0.017 & 0.054 & 0.430 \\
LSD $(\mathrm{P}<0.05)$ & $\mathrm{ns}$ & $\mathrm{ns}$ & 5.231 & 3.215 & 5.526 & 21.635 & 0.0021 & 0.0031 & 0.0143 \\
\hline
\end{tabular}

number of leaves with $\mathrm{r}=0.66$ and 0.57 at 6 and 8 WAP, respectively.

The unfertilized plants had lower LA due to less number of leaves resulting from premature leaf fall and early vine senescence (Okwuowulu, 1995). The higher LAI associated with the fertilized plants was probably due to higher number of leaves.

The leaf index increased as fertilizer rate increased with correlation coefficient of 0.66 at 6 WAP in both years. Plants fertilizer with $600 \mathrm{~kg} \backslash$ ha had the greatest LAI which was $1200 \%$ higher than the unfertilized plants. This pattern of distribution was maintained at 8 WAP. There was significant correlation between number of leaves and LAI $(r=0.68)$. This is a pointer to the fact that changes in numbers of leaves are bound to alter the overall performance of the plant as the leaf serves as the photosynthetic organ of the plant.

TDM was higher in plants that received $600 \mathrm{~kg} \mathrm{NPK} \mathrm{/}$ ha than those that received 0 and $400 \mathrm{~kg} \mathrm{ha}^{-1}$ (Tab. 3). The dry matter production at $600 \mathrm{~kg} \mathrm{ha}^{-1}$ was higher in TDM than at 400,200 and $0 \mathrm{~kg} \mathrm{ha}^{-1}$ by $11.76 \%, 19.49 \%$ and $115 \%$, respectively. This trend has earlier been reported by Olufolaji et al. (2002) in a comparative evaluation on soil and foliar applied fertilizer on growth and yield of Celocia argentea reported increase in TDM. This may be attributed to NPK being part of the essential nutrients required for the production of the meristematic and physiological activities such as leaves, roots, shoots, dry matter production, etc leading to an efficient translocation of water and nutrients, interception of solar radiation and carbon dioxide. This activities promote greater photosynthetic activi- ties of adequate assimilates for subsequent translocation to various sinks and hence the production of higher TDM (Jaliya et al., 2008).

The effect of NPK fertilizer application on fresh cob yield followed the same trend as in TDM (Tab. 3). As observed in TDM, NPK increased significantly fresh cob as the rate increases. The untreated plants produced the least value. Fresh cob yield was significantly higher in plants treated with $600 \mathrm{~kg} \mathrm{ha}^{-1}$ than those treated with 400, 200 and $0 \mathrm{~kg} \mathrm{ha}^{-1}$ by $24.46 \%, 53.35 \%$ and $282.5 \%$, respectively. The highest $(12.44 \mathrm{t} / \mathrm{ha})$ dry yields were obtained at $400 \mathrm{~kg} \mathrm{ha}^{-1}$ treated plants, whilst the untreated plants had the least $\left(4.07 \mathrm{t} \mathrm{ha}^{-1}\right)$. The dry cob yields obtained with the application of 600, 400 and $200 \mathrm{~kg} /$ ha were 191.15 $\%, 205.65 \%$ and $160.20 \%$ greater than the untreated control, respectively.

The grain yields were significantly affected by NPK fertilizer application at all levels. The pattern of response was very clear, with lowest grain yield obtained from plants treated without fertilizer treatment, whilst the highest grain yields were obtained at $400 \mathrm{~kg} / \mathrm{ha}$ (Tab. 3). These findings are in lined with the view of Adediran and Banjoko (2003) but contrary to that of Ayoola and Adeniyan (2006) who reported that the use of inorganic fertilizer is associated with reduced crop yield. Based on pooled analysis between the two years, there was no significant difference on yield. The results of this trial showed that NPK application increased fresh grain yield. From this study, the average yield varied from 3.52 to $7.95 \mathrm{tha}^{-1}$ between 0 and $400 \mathrm{~kg} \mathrm{ha}^{-1}$ suggests that the $400 \mathrm{~kg} \mathrm{ha}^{-1}$ may be regarded as the optimum level of the nutrient elements while the

Tab. 3. Total dry matter and yield attributes as affected by different levels NPK 15:15:15 fertilizer application on maize (Zea mays)

\begin{tabular}{cccccccc}
\hline Fertilizer rate & TDM & Fresh cob yield & Dry cob yield & Grain yield & Relative grain & Weight of \\
\hline$\left(\mathrm{kg} \mathrm{ha}^{-1}\right)$ & $\left(\mathrm{t} \mathrm{ha}^{-1}\right)$ & $\left(\mathrm{t} \mathrm{ha}^{-1}\right)$ & $\left(\mathrm{t} \mathrm{ha}^{-1}\right)$ & $\left(\mathrm{t} \mathrm{ha}^{-1}\right)$ & yield & 1.00 & $1.90^{- \text {seeds }}(\mathrm{g})$ \\
\hline 0 & 4.82 & 5.32 & 4.07 & 3.52 & 7.01 & 7.99 & 10.56 \\
200 & 8.67 & 13.27 & 10.59 & 12.44 & 7.95 & 2.26 & 11.62 \\
400 & 9.27 & 16.35 & 11.85 & 5.85 & 1.66 & 10.75 \\
600 & 10.36 & 20.35 & 9.74 & 6.08 & 1.73 & 10.59 \\
Mean & 8.28 & 13.82 & 0.56 & 1.22 & 0.56 & 0.58 \\
\hline LSD $(\mathrm{P}<0.05)$ & 1.30 & 2.16 & & & & \\
\hline
\end{tabular}


62

$600 \mathrm{~kg} \mathrm{ha}^{-1}$ may be said to be toxic level, since it retarded growth (dry matter accumulation) and grain yield. Such excessive inorganic fertilizer application can induce nutrient imbalance, acidity, pollution of ground water resulting from leaching and reduce palatability (Sridher and Adeoye, 2003). This could be as a result of interference in the absorption and utilization of other elements that would have improved yield (Uguru, 1996). The plants without fertilizer treatment had the lowest yield which could have been partly due to deficiency of nutrients as revealed by low nutrient status of the soil. The difference in the optimum levels of NPK fertilizer rate in both years may be attributed to differences in the nutrient reserve in the soils.

The effect of NPK fertilizer on relative grain yield and 100-seeds weight followed the same trend as observed in grain yield (Tab. 3). NPK fertilizer treated plants produced significantly higher relative grains and 100-seeds weight than the untreated plants at levels of application. The least values for the two parameters were produced by the untreated plants ( 1.00 for relative grain yield and $9.43 \mathrm{~g}$ for the weight of 100-seed. The relative grain yields were greatest (2.26) for plants treated with $400 \mathrm{~kg} \mathrm{ha}^{-1}$. This is a reflection of the fact that there is positive relationship between grain yield improvement and economic viability in maize production. For the weight of 100-seeds, $400 \mathrm{~kg}$ / ha treated plants had the greatest $(11.62 \mathrm{~g})$. This implies that NPK fertilizer application has significant effect on the seed size and then and then made it bigger as the level of application increases.

This investigation revealed that NPK 15:15:15 fertilizer rates have a profound effect on the overall performance of maize. Application of NPK fertilizer at the different levels used in this study had significantly effect on the growth and yield of maize. Fertilizer application level of $400(60$ $\mathrm{kg} \mathrm{N}+27.16 \mathrm{~kg} \mathrm{P}+49.80 \mathrm{~kg} \mathrm{~K}) \mathrm{kg} / \mathrm{ha}$ is effective for the optimum growth and yield of maize.

\section{References}

Adediran, J. A. and V. A. Banjoko (2003). Comparative effectiveness of some compost fertilizer formulations for maize in Nigeria. Nig. J. Soil Sci., 13:42-48.

Ayoola, O. T. and O. N. Adeniyan (2006). Influence of poultry on yield and yield components of crops under different cropping systems in South west Nigeria. African J. Biotechnology, 5:1386-1392.

Babatola, I. A. (2006). Effects of NPK 15:15:15 fertilizer on the performance and storage life of okra (Abelmuschus esculentus). Proceedings of the Horticultural Society of Nigeria Conference, pp. 125-128.

FAO. (2007). Food and Agriculture Organisation yearbook Volume 60.

Fashina, A. S., K. A. Olatunji and K. O. Alasiri (2002). Effects of different plant population and poultry manure on yield of Ugu (Telfairia occidentalis) in Lagos State, Nigeria in
Proceedings of the annual Conference of Horticultural Society of Nigeria (HORTON), pp. 123-127.

ISTA. (1993). International Rules for Seed Testing Association. Seed Sci. Technology, Supplementary rule, Volume 21.

Jaliya, A. M., A. M. Falaki, M. Mahmud and Y. A. Sani (2008). Effects of sowing date and NPK fertilizer rate on yield and yield components of quality protein maize (Zea mays L.). ARPN J. Agric. Biological Sci., 2:23-29.

Mylavapus, R.S andD.E.Kennelley(2002).UF//IFAS extension soil testing laboratory (ESTL): Analytical procedures and training manual. Institute of Food and Agricultural Science, University of Florida, Gainesville, USA., 28p.

Obi, C. O., P. C. Nnabude and E. Onucha (2005). Effects of kitchen waste compost and tillage on soil chemical properties and yield of Okra (Abelmuschus esculentus), Soil Sci., 15:6976.

Okwuowulu, P. A. (1995). Yield response to edible yam (Dioscorea sp.) to time of fertilizer application and age at harvest in an Ultisol in the humid zone of Southeastern Nigeria. African Journal of Root and Tuber Crops, 1: 6-10.

Olufolaji, A. O., A. A. Kintomo and K. O. Alasiri (2002). Comparative evaluation of soil applied and foliar fertilizer on the growth of "Sokoyoko" (Celosia argentea). The Plant Scientist, 3:73-80.

SAS Institute, (2004). SAS user's guide. Statistic, version 9.0. Statistic Institute Inc. Cary, North Carolina, USA. 1028p.

Stefano, P., R. Dris and F. Rapparini (2004). Influence of growing conditions and yield and quality of cherry. II. Fruit. J. Agric. And Env., 2:307-309.

Steiner, K. G. (1991). Overcoming soil fertility constraints to crop production in West Africa. Impart of traditional and improved cropping systems on soil fertility, pp. 69-91.

Saeed, I. M., R. Abbasi and M. Kazim (2001). Response of maize (Zea mays) to nitrogen and phosphorus fertilization under agro-climatic condition of Rawalokol, Azad Jammu and Kaslim and Kashmir, Pak. J. Biological Sci., 4: 949-952.

Sridhar, M. K. C. and G. O. Adeoye (2003). Organo-mineral fertilizer from urban wastes. The Field, 68:91-111.

Uguru, M. I. (1996). Crop production techniques. Fulladu Publication Company, Nsukka, Nigeria.

Uyoubisere, E. O., V. O. Chude and A. Bationo (2000). Promising nutrient ratios in the fertilizer formulations for optimal performance of maize in Nigerian savanna. The need for a review of current recommendations. Nig. Soil Res., 1:29-34. 